\title{
Metabolic Changes Induced by Purinergic Signaling: Role in Food Intake
}

\author{
Vanni Caruso ${ }^{1,2 \dagger}$, Mariachiara Zuccarini ${ }^{3,4 t}$, Patrizia Di lorio ${ }^{3,4}$, Ishaq Muhammad ${ }^{1}$ and \\ Maurizio Ronci ${ }^{4,5 *}$
}

${ }^{1}$ School of Pharmacy and Pharmacology, University of Tasmania, Hobart, TAS, Australia, ${ }^{2}$ Institute for Research on Pain, ISALFoundation, Rimini, Italy, ${ }^{3}$ Department of Medical, Oral and Biotechnological Sciences, University of Chieti-Pescara, Chieti, Italy, ${ }^{4}$ Center for Advanced Studies and Technologies (CAST), University of Chieti-Pescara, Chieti, Italy, ${ }^{5}$ Department of Pharmacy, University of Chieti-Pescara, Chieti, Italy

OPEN ACCESS

Edited by:

Peter Illes,

Leipzig University, Germany

Reviewed by:

Elizabeth Ruth Gilbert,

Virginia Tech, United States

Luigi Bellocchio,

INSERM U1215 Neurocentre

Magendie, France

*Correspondence:

Maurizio Ronci

maurizio.ronci@unich.it

${ }^{t}$ These authors have contributed equally to this work and share first authorship

Specialty section: This article was submitted to Experimental Pharmacology and Drug Discovery,

a section of the journal

Frontiers in Pharmacology

Received: 19 January 2021 Accepted: 09 April 2021

Published: 29 April 2021

Citation:

Caruso V, Zuccarini M, Di lorio P. Muhammad I and Ronci M (2021)

Metabolic Changes Induced by

Purinergic Signaling: Role in

Food Intake.

Front. Pharmacol. 12:655989. doi: 10.3389/fphar.2021.655989
The purinergic signalling has a well-established role in the regulation of energy homeostasis, but there is growing evidence of its implication in the control of food intake. In this review, we provide an integrative view of the molecular mechanisms leading to changes in feeding behaviour within hypothalamic neurons following purinergic receptor activation. We also highlight the importance of purinergic signalling in metabolic homeostasis and the possibility of targeting its receptors for therapeutic purposes.

Keywords: purinergic receptors, food intake, metabolic homeostasis, orexigen and anorexigen neurons, obesity

\section{INTRODUCTION}

The purinergic system consists of a ubiquitous and complex network of intracellular and extracellular components that mediates cell growth and differentiation, neuroprotection, inflammation, and several neuroendocrine functions including energy homeostasis and food intake (Coccurello and Volonté, 2020; Jain and Jacobson, 2020). The regulatory role of the purinergic system is determined by the activity of adenine- and guanine-based compounds, their converting enzymes, as well as P1 and P2 receptors (Burnstock, 2011; Yegutkin, 2014). Specifically, P1 include four adenosine (Ado) receptors (A1, A2A-B, A3), whereas $\mathrm{P} 2$ receptors bind both nucleotides and nucleotide sugars (ATP, ADP, UTP, UDP, UDP-glucose) (Fredholm et al., 2011). $A_{1}$ and $\mathrm{A}_{3}$ metabotropic receptors couple to the $\mathrm{G}_{\mathrm{i} / \mathrm{o}}$ family and inhibit cyclic AMP (cAMP) production, whereas $A_{2 A}$ and $A_{2 B}$ are stimulatory $G_{s}$-protein coupled receptors enhancing cAMP production; $\mathrm{P} 2 \mathrm{X}_{1-7}$ receptors are ligand-gated ion channels that, following ATP binding, open the pore permeable to $\mathrm{Na}^{+}, \mathrm{K}^{+}$, and $\mathrm{Ca}^{2+} ; \mathrm{P}_{2} \mathrm{Y}_{1-2-4-11}$ are metabotropic receptors activating phospholipase $\mathrm{C}$ (PLC)/inositol triphosphate (IP3)/Ca ${ }^{2+}$ axis via $\mathrm{G}_{\mathrm{q}} / \mathrm{G}_{11}$ proteins whereas $\mathrm{P} 2 \mathrm{Y}_{12-13-14}$ are coupled to $G_{i} / G_{o}$ (Burnstock, 2020). After being released in the extracellular milieu, ATP is hydrolyzed to Ado via a sequential series of enzymatic reactions catalyzed by several ecto-nucleotidases: ecto-nucleoside triphosphate diphosphorylases (CD39), ecto-5'-nucleotidase (CD73), ecto-nucleotide pyrophosphatase/phosphodiesterases (NPP) and alkaline phosphatases (APs) (Zimmermann et al., 2012; Losenkova et al., 2018). Extracellular nucleosides are, then, taken up by the cells via equilibrative nucleoside transporters (ENTs) and concentrative nucleoside transporters (CNTs) and ultimately interconverted to generate purine nucleotides by de novo synthesis or via the purine salvage pathway.

The dysregulation of the purinergic signaling has been associated with important pathophysiological conditions including neurodegenerative diseases, cancer, inflammation and 
TABLE 1 | Purinergic receptors in food intake and cell metabolism.

\begin{tabular}{|c|c|c|c|}
\hline Receptor & $\begin{array}{l}\text { Endogenous } \\
\text { agonists }\end{array}$ & Functional role & References \\
\hline $\mathrm{A} 1$ & Ado & $\begin{array}{l}\text { Adipogenesis, lipolysis, lipogenesis, glycogenolysis, } \\
\text { gluconeogenesis, energy expenditure, feeding, obesity }\end{array}$ & $\begin{array}{l}\text { González-Benítez et al. (2002), Barakat et al. (2006), } \\
\text { Faulhaber-Walter et al. (2011), Gnad et al. (2014), Tozzi and Novak } \\
\text { (2017), Wu et al. (2017) }\end{array}$ \\
\hline $\mathrm{A} 2 \mathrm{~A}, \mathrm{~A} 2 \mathrm{~B}$ & Ado & $\begin{array}{l}\text { Thermogenesis, adipogenesis, lipolysis, lipogenesis, } \\
\text { glycogenolysis, gluconeogenesis browning, insulin homeostasis, } \\
\text { hepatic inflammation, regulation of food intake }\end{array}$ & $\begin{array}{l}\text { González-Benítez et al. (2002), Krügel et al. (2003), Yasuda et al. } \\
\text { (2003), Carmen and Víctor (2006), Greenberg et al. (2006), } \\
\text { Johansson et al. (2007), Gharibi et al. (2012), Kusminski et al. } \\
\text { (2016), DeOliveira et al. (2017), Tozzi and Novak (2017), Cai et al. } \\
\text { (2018), Gnad et al. (2020), Sacramento et al. (2020) }\end{array}$ \\
\hline $\mathrm{P} 2 \mathrm{X} 2$ & ATP & Metabolic homeostasis (orexigenic effect) & $\begin{array}{l}\text { Lee et al. (2005), Wollmann et al. (2005), Florenzano et al. (2006), } \\
\text { Colldén et al. (2010), Sun et al. (2012), Li et al. (2015), D’Alimonte } \\
\text { et al. (2017), Wang et al. (2020) }\end{array}$ \\
\hline P2X5 & ATP & Thermogenesis & Nascimento et al. (2014) \\
\hline $\mathrm{P} 2 \times 7$ & ATP & Inflammation, adipocyte hypertrophy, dyslypidemia, obesity & (Beaucage et al. (2014), Coccurello and Volonté (2020) \\
\hline $\mathrm{P} 2 \mathrm{Y} 1$ & ADP & $\begin{array}{l}\text { Regulation of food intake, leptin production, glucose-stimulated } \\
\text { insulin response, adipogenesis }\end{array}$ & $\begin{array}{l}\text { Léon et al. (2005), Seidel et al. (2006b), Kittner et al. (2006), } \\
\text { Laplante et al. (2010) }\end{array}$ \\
\hline P2Y2 & ATP; UTP & $\begin{array}{l}\text { Release of pro-inflammatory cytokines (MCP-1, CD68, } \\
\text { adipocytokines), glucose homeostasis, obesity, adipogenesis, } \\
\text { insulin sensitivity }\end{array}$ & $\begin{array}{l}\text { Laplante et al. (2010), Tozzi and Novak (2017), Merz et al. (2018), } \\
\text { Zhang et al. (2020) }\end{array}$ \\
\hline P2Y4 & ATP, UTP & Adipogenesis & Tozzi and Novak (2017) \\
\hline P2Y6 & UDP & $\begin{array}{l}\text { Regulation of food intake, glucose uptake, diet-induced obesity, } \\
\text { inflammation, insulin resistance }\end{array}$ & $\begin{array}{l}\text { Balasubramanian et al. (2014), Steculorum et al. (2015a), } \\
\text { Steculorum et al. (2017b), Jain et al. (2020) }\end{array}$ \\
\hline
\end{tabular}

metabolic disorders such as obesity (Tozzi and Novak, 2017; Burnstock and Gentile, 2018; Boison and Yegutkin, 2019).

$\mathrm{P} 1$ and $\mathrm{P} 2$ receptors are expressed in metabolically active tissues (e.g., brain, adipose tissue, skeletal muscle, immune system, pancreas, liver) where they regulate gluconeogenesis, inflammation, lipolysis/lipogenesis, insulin sensitivity, energy expenditure, thermogenesis and food intake (Table 1). For an exhaustive review, (Jain and Jacobson, 2020).

Purinergic receptors are ubiquitously expressed in the central nervous system (CNS) including the hypothalamus, an integral part of the limbic system consisting of a complex architecture of neurons organized in small nuclei that are involved in the regulation of several neuroendocrine functions (Lechan, 2016), including the control of food intake (Timper and Brüning, 2017).

Activation of Agouti-related peptide (AgRP) neurons, a small subset of neurons in the hypothalamic arcuate nucleus (ARC), potently promotes rapid feeding (Aponte et al., 2011), whereas ablation of AgRP neurons results in satiety (Gropp et al., 2005).

The abundant expression of purinergic receptors in the ARC, lateral hypothalamus (LH), paraventricular nucleus (PVN) and, specifically, in hypocretin/orexin neurons, suggests that the purinergic system may play a major role in the regulation of food intake (Florenzano et al., 2006). Anatomically, an abundant expression of $\mathrm{P} 2 \mathrm{X}_{2,4,6}$ receptors is found in the neurons of the $\mathrm{ARC}$, whereas a similar receptorial density of $\mathrm{P} 2 \mathrm{X}_{1-6}$ receptors is expressed in the PVN where ATP release elicits fast excitatory synaptic transmission (Cham et al., 2006).

Noteworthy, recent studies highlighted the coordinated action of different brain cells (tanycytes, astrocytes, microglia) as well as neuronal-glial interactions in the orchestration of energy homeostasis Andermann, M. L., and Lowell, B. B. (2017). Toward a wiring diagram under-standing of appetite control. Neuron, 95 (4),757-778. https://doi.org/10.1016/j.neuron. 2017.
06.014). Astrocytes and microglia are secretory cells that release neuroactive compounds, including purines, in the extracellular milieu, thus contributing to regulate synaptic plasticity and cell adaptation under different stimuli (Peña-Altamira et al., 2018; García-Cáceres et al., 2019). Beyond their well-documented role of structural support and neurotransmission, astrocytes and microglia have been drawing attention for their effect in nutrients and hormone sensing, by virtue of the expression of purinergic, GABAergic and Toll-like receptors (Kettenmann et al., 2011; García-Cáceres et al., 2016). Accordingly, it has been reported that an hypercaloric diet enhance astrogliosis in the ARC, thus suggesting a role of these cells in the pathogenesis of obesity (Balland and Cowley, 2017).

In the present review we illustrate the state-of-the-art of purine modulation of food intake, by taking into account the complex interaction between purinergic signaling with hormones and brain circuits within the hypothalamus and the surrounding regions.

\section{Role of Purinergic Signalling in Food Intake}

Food intake is the result of metabolic, autonomic, environmental and neuroendocrine factors integrated within the hypothalamus, the central hub regulating energy homeostasis (Bernardis and Bellinger, 1996). There is a compelling evidence that purinergic receptors have highly overlapping expression patterns as well as binding profiles in hypothalamic regions (Abbracchio et al., 2009).

Neurophysiologic findings demonstrated that ATP administration on hypothalamic slices induced a dose dependent increase in spike frequency of orexin neurons (Wollmann et al., 2005) and dorsomedial hypothalamic neurons (Matsumoto et al., 2004) and that the entire population of orexigenic neurons express the purinergic 


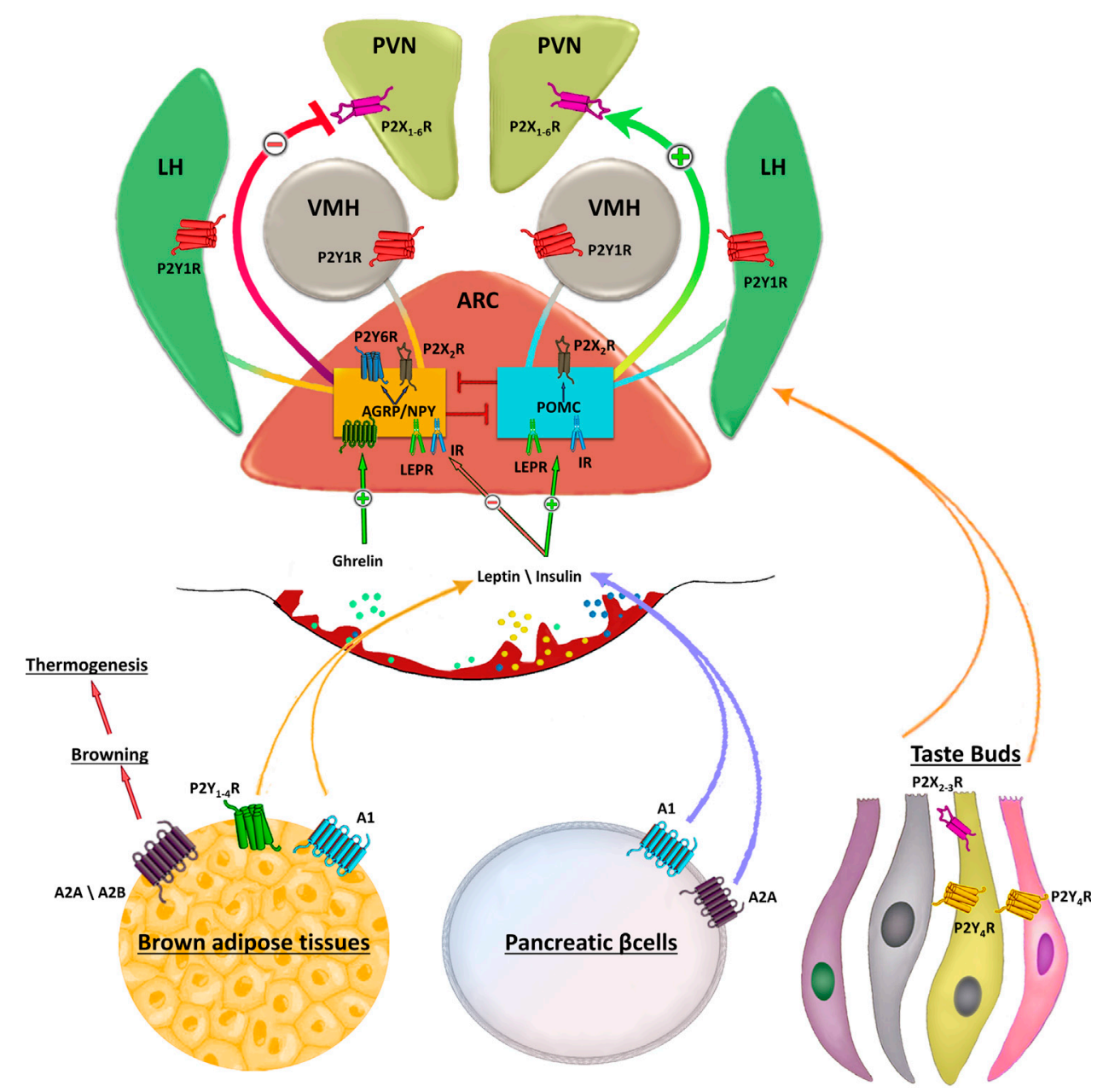

FIGURE 1 | Schematic representation of purinergic signalling in hypothalamus. In the hypothalamus, purinergic signalling is involved in several complex aspects regulating food intake. Endogenous appetite stimulants such as ghrelin promotes food intake inactivating the anorexigenic proopiomelanocortin (POMC) neurons activity, while leptin inhibits the orexogenic signalling of AgRP/NPY neurons. Purinergic receptors are abundantly expressed in the ARC, paraventricular nucleus (PVN), lateral hypothalamus $(\mathrm{LH})$. Strong P2X2R immunoreactivity is found in cell bodies of orexigenic NPY/AGRP/GABA neurons in the ARC and only occasionally in cell bodies of neurons expressing anorexigenic peptides. AgRP neurons also express UDP-activated P2Y6R. The ventromedial (VMH) and lateral hypothalamus (LH) are brain regions with antagonistic functions in the regulation of food intake in which activation of VMH neurons inhibits feeding, whereas stimulation of $\mathrm{LH}$ neurons enhances food intake. Peripheral stimulation of purinergic receptors in brown adipose tissue, pancreatic $\beta$-cells or taste buds regulates the circulating levels of leptin, insulin and other factors involved in food intake. Stimulation of A2A A2B receptors induces browning of adipose tissue that in turn increases thermogenesis thus preventing fat accumulation.

subtype receptor $\mathrm{P} 2 \mathrm{X}_{2} \mathrm{R}$ (Florenzano et al., 2006). Specifically, strong $\mathrm{P} 2 \mathrm{X}_{2} \mathrm{R}$ immunoreactivity is found in cell bodies of orexigenic NPY/AGRP/GABA neurons in the ARC (Colldén et al., 2010).

The latest and most specific evidence regarding the potential therapeutic usage of purinergic compounds in obesity arises from physiological studies at the receptor level using transgenic mice and synthetic ligands. Recent evidence of the involvement of the purinergic system in the regulation of food intake suggest that also the UDP-activated P2Y6R is expressed in AgRP neurons (Steculorum et al., 2015b). In obesity, hypothalamic UDP concentrations are elevated as a result of an increased circulating source of uridine, and this elevation might overstimulate feeding via P2Y6-dependent activation of AgRP neurons (Steculorum et al., 2015b). The development of selective antagonists for purinergic receptors has corroborated the evidence that pharmacologic inhibition of P2Y6R signaling in AgRP neurons reduces food intake and improves systemic insulin sensitivity in obese mice (Steculorum et al., 2017a).

Functional studies in animal models have produced exciting discoveries on the role of purinergic signaling in the regulation of food intake. Changes in feeding conditions, from ad libitum to intermittent restriction, have proved to alter the hypothalamic $\mathrm{P} 2 \mathrm{Y} 1$ receptor expression in rats (Seidel et al., 2006a). 
Immunohistochemical staining indicated that P2Y1 receptors and neuronal nitric oxide synthase (nNOS) co-localize in neurons of the ventromedial hypothalamic nucleus (VMH) and LH (Kittner et al., 2006), two functionally antagonistic regions involved in the regulation of food intake (Timper and Brüning, 2017) in which activation of VMH neurons inhibits feeding, whereas stimulation of $\mathrm{LH}$ neurons enhances food intake (Brown et al., 1984; Takaki et al., 1992). A direct coupling between purinergic signaling and NOS activity during adaptive feeding processes was tested in rats with microinjections of $\mathrm{P} 2 \mathrm{Y} 1$ agonists into both VMH and LH (Kittner et al., 2006). The authors demonstrated that ATP/ADP, acting as extracellular signal molecules in the rat brain, are involved in the regulation of food intake, plausibly depending on P2Y1-receptor-mediated nitric oxide production (Kittner et al., 2004) (Figure 1).

It has been very recently reported that adenosine receptors may play a central role in the management of obesity and metabolic disorders (D’Antongiovanni et al., 2020; de Oliveira et al., 2020). Stimulation of A2A and A2B receptors by specific agonists increased lipolysis and brown adipose tissue (BAT) thermogenesis, and protected mice from diet-induced obesity (Gnad et al., 2014). Increasing thermogenesis via the metabolic activity of BAT has been considered as a pharmacological intervention able to fight the energy imbalance underlying weight gain and obesity (Gnad et al., 2014). Therefore, the thermogenic/lipolytic effects of Ado via activation of BAT and, subsequently, fat catabolism, could be a promising approach to address metabolic disorders. An increased expression of A1R in thermoregulatory neurons has been associated with obesity in mice, whereas stimulatory doses of the purine alkaloid caffeine, a non-selective A1R antagonist, was able to decrease body weight and increase brown adipose tissue (BAT) thermogenesis in rats fed a HFD (Collden et al., 2010; Wu et al., 2017). Research efforts have also provided a direct evidence that adenosine receptors in hypothalamic glia cells could play a role in feeding responses (Yang et al., 2015). Combined chemical genetics, cell-typespecific electrophysiology, pharmacology, and feeding assays demonstrated that stimulation of astrocytes within the medial basal hypothalamus reduces both basal- and ghrelin-evoked food intake (Yang et al., 2015). Specifically, activation of A1 receptors mediated the astrocytic inhibition of food intake and the firing rate of AGRP neurons suggesting that the glial circuit could be a novel target for therapeutic intervention in the treatment of appetite disorders (Yang et al., 2015).

Recent interest on the role of glia cells in food intake focuses on the roles of hypothalamic tanycytes, chemosensitive glial cells with a unique morphology. Hypothalamic tanycytes are in contact simultaneously with the cerebrospinal fluid (CSF) in the third ventricle and with major neural populations in the hypothalamic parenchyma (Bolborea and Dale, 2013; Goodman and Hajihosseini, 2015). Physiologically, tanycytes can sense nutrients such as glucose and amino acids in the CSF evoking robust ATP-mediated Ca2+ responses (Frayling et al., 2011; Orellana et al., 2012). The release of ATP in response of glucose or amino acids results in the activation of purinergic receptors in hypothalamic neurons of the arcuate and ventromedial nucleus (Bolborea et al., 2020). Specifically, optogenetic studies demonstrated that tanycytes can activate purinergic receptors in orexigenic NPY-expressing neurons in the ARC to induce acute hyperphagia when activated by light (Bolborea et al., 2020). Taken together, tanycytes sense the elevation of glucose and amino acids in plasma and CSF following a meal, and in response, they release ATP into hypothalamic neurons activating anorexigenic pathways to reduce appetite.

There is a consensus that ATP and adenosine are also involved in the rewarding effects of feeding in a functionally antagonistic manner (Krügel et al., 2003; Kittner et al., 2004).

Animal studies demonstrated that stimulation of ADP/ATP sensitive $\mathrm{P} 2$ receptors in the nucleus accumbens (NAc), a primary site mediating reward behaviour, reinforced their dopaminergic responses and enhanced food intake (Krügel et al., 2001), while the blockade of P2 receptors decreased their feeding responses associated with dopamine release (Kittner et al., 2000). In an elegant behavioural study where microdialysis was combined with encephalographic measurements, injections of non-selective P2 and $\mathrm{P} 1$ receptor antagonists in the NAc of rats, PPADS and 8-SPT respectively, interacted antagonistically in the regulation of feeding behaviour and feeding-induced changes of EEG activity (Kittner et al., 2004). Other evidence indicate that adenosine suppressed dopamine release via agonism of the $\mathrm{A}_{2 \mathrm{~A}}$ receptors in the NAc and this was accompanied with the reduction in food intake (Krügel et al., 2003), whereas the agonism of the A1 receptor was not involved in feeding responses (Krügel et al., 2003; Mingote et al., 2008). This might suggest that selective blockage of purinergic receptors in the NAc modulates the rewarding effects of feeding behaviour. Beyond the established hypothalamic-mesolimbic pathway circuitry for the regulation of food intake, a diverse array of detectors in the oral cavity including taste receptors in the tongue play a pivotal role in the modulation of energy homeostasis mechanisms (Chaudhari and Roper, 2010; Depoortere, 2014).

Taste buds are a collection of gustatory sensory cells that release ATP, among other neurotransmitters such as acetylcholine, serotonin, norepinephrine or GABA in response to gustatory stimulation (Khan et al., 2020). The release of these molecules enhance the communication with the gustatory centre of the brain (i.e. the insular cortex and then hypothalamus) through cranial nerves including the glossopharyngeal nerve, the facial nerve and the vagus nerve (Frank and Hettinger, 2005). Specifically, in response to gustatory stimulation, ATP and neurotransmitters are released to enable chemical signalling within the taste bud itself or with afferent sensory nerves that express $\mathrm{P} 2 \mathrm{X} 2 / \mathrm{P} 2 \mathrm{X} 3$ receptors on the nerve fibers innervating the taste buds. (Chaudhari and Roper, 2010).

Taste buds are divided in four morphological subtypes: Types I, II, III, and IV and among these subtypes, type II cells are the most characterised (Nelson et al., 2001; Depoortere, 2014). ATP is released by Type 2 cells in response to sweet, bitter or umami testants (Besnard et al., 2016) and genetic inactivation of $\mathrm{P} 2 \mathrm{X} 2 / \mathrm{P} 2 \mathrm{X} 3$ receptors in nerve fibres is associated with decreased salty and sour tastes (Finger et al., 2005). Once released, ATP can also activate adjacent Type 3 cells triggering the release of serotonin which contribute to prolong the transmission of the taste signals to the brain (Besnard et al., 2016).

In the obese, the number and density of the taste buds is reduced by $25 \%$ compared to healthy individuals suggesting that 
overeating could be associated with impairments in purinergic afferent reward-induced signalling (Proserpio et al., 2015; Coccurello and Maccarrone, 2018; Kaufman et al., 2018).

\section{DISCUSSION}

During the past 4 decades, purinergic signalling has received considerable attention regarding its involvement in the fine regulation of food intake. The advent of new molecular tools, conditional knockout strategies targeting specific neuronal populations as well as animal behavioural models have shed further light on this function. For example, since when hypothalamic gliosis was associated with inflammation resulting from high-fat diet feeding in both rodents and human (Thaler et al., 2012), several investigations on nonneuronal cells have since been reported in energy homeostasis and obesity pathogenesis (Douglass et al., 2017). There are direct evidence that adenosine receptors, in particular A1R, in hypothalamic glia cells play a role in feeding responses (Yang et al., 2015), as endogenous Ado inhibited basal food intake and counter-regulated the ghrelin-elicited feeding by inactivating the orexigenic AGRP neurons in the ARC.

Moreover, nutrient sensing tanycytes activate the arcuate neuronal network releasing ATP and promoting acute hyperphagia (Bolborea et al., 2020). It has been demonstrated that the long-term exposure to high fat diet induces hypothalamic gliosis (Douglass et al., 2017) and given the dramatic increase in childhood obesity, the question whether homeostasis-challenging circumstances on purinergic signalling early in life could predispose to a multifactorial and complex disease in adulthood, is still a matter of debate.

Purinergic signalling also plays a major role in the regulation of peripheral sensory pathways of the gustatory system for the regulation of food intake (Besnard et al., 2016). To date, the majority of anti-obesity agents targeting signalling pathways in metabolic tissues such as liver, adipocytes and skeletal muscles have failed to deliver significant clinical results (Rodgers et al., 2012). Targeting the gustatory signalling pathways could represent a promising and effective strategy that can provide clinically relevant anti-obesity agents.

\section{REFERENCES}

Abbracchio, M. P., Burnstock, G., Verkhratsky, A., and Zimmermann, H. (2009). Purinergic Signalling in the Nervous System: an Overview. Trends Neurosciences 32 (1), 19-29. doi:10.1016/j.tins.2008.10.001

Aponte, Y., Atasoy, D., and Sternson, S. M. (2011). AGRP Neurons Are Sufficient to Orchestrate Feeding Behavior Rapidly and without Training. Nat. Neurosci. 14 (3), 351-355. doi:10.1038/nn.2739

Balasubramanian, R., Robaye, B., Boeynaems, J.-M., and Jacobson, K. A. (2014). Enhancement of Glucose Uptake in Mouse Skeletal Muscle Cells and Adipocytes by P2Y6 Receptor Agonists. PLoS One 9 (12), e116203, doi:10.1371/journal.pone.0116203

Balland, E., and Cowley, M. A. (2017). Short-term High-Fat Diet Increases the Presence of Astrocytes in the Hypothalamus of C57BL6 Mice without Altering Leptin Sensitivity. J. Neuroendocrinol 29 (10), e12504. doi:10. 1111/jne.12504
The protection from diet-induced obesity through the thermogenic/lipolytic effects of Ado, may be mediated by the metabolic activity of BAT via the autonomic nervous system stimuli originating from the dorsomedial hypothalamic nucleus (DMN) in a loop mechanism.

The multiple roles of the purinergic signalling in the regulation of food intake are both an opportunity for therapeutic interventions, but also a concern when considering the risk of side effects of a new compound. Noteworthy, the translation from studies in mice to clinical trials in humans is still a big challenge due to many factors, including the heterogeneity of the cells forming the neuronal circuits which are difficult to study singularly and attribute them an univocal function separated from the dynamic microenvironment, as well as the ubiquitous expression of purinergic receptors that, in the absence of specific agonist/antagonist, generate compensatory mechanisms blurring their specific role. The neuroanatomical interactions of purinergic signalling within hypothalamic circuits and the nucleus accumbens might suggest the design of multifunctional compounds able to target their respective receptors separately, which may result in a greater therapeutic effect for the cure of obesity and immunometabolic disorders. Among others, P2Y6R, P2X7R or A1 specific inhibitors may represent novel therapeutic tools in the management of diet-induced obesity.

Taken together, purinergic signalling between brain regions involved in motivation, reward and energy homeostasis present a novel and valid target for the control of feeding behaviour, where selective pharmacological intervention might produce promising results.

\section{AUTHOR CONTRIBUTIONS}

All authors listed have made a substantial, direct and intellectual contribution to the work, and approved it for publication.

\section{FUNDING}

This study was partially supported by funds to PD and MR from the Italian Ministry of Education, University and Research (MIUR).

Barakat, H., Davis, J., Lang, D., Mustafa, S. J., and McConnaughey, M. M. (2006). Differences in the Expression of the Adenosine Al Receptor in Adipose Tissue of Obese Black and White Women. J. Clin. Endocrinol. Metab. 91 (5), 1882-1886. doi:10.1210/jc.2005-2109

Beaucage, K. L., Xiao, A., Pollmann, S. I., Grol, M. W., Beach, R. J., Holdsworth, D. W., et al. (2014). Loss of P2X7 Nucleotide Receptor Function Leads to Abnormal Fat Distribution in Mice. Purinergic Signal. 10 (2), 291-304. doi:10.1007/s11302-013-9388-x

Bernardis, L. L., and Bellinger, L. L. (1996). The Lateral Hypothalamic Area Revisited: Ingestive Behavior. Neurosci. Biobehavioral Rev. 20 (2), 189-287. doi:10.1016/0149-7634(95)00015-1

Besnard, P., Passilly-Degrace, P., and Khan, N. A. (2016). Taste of Fat: A Sixth Taste Modality?. Physiol. Rev. 96 (1), 151-176. doi:10.1152/physrev.00002.2015

Boison, D., and Yegutkin, G. G. (2019). Adenosine Metabolism: Emerging Concepts for Cancer Therapy. Cancer Cell 36 (6), 582-596. doi:10.1016/j. ccell.2019.10.007 
Bolborea, M., and Dale, N. (2013). Hypothalamic Tanycytes: Potential Roles in the Control of Feeding and Energy Balance. Trends Neurosciences 36 (2), 91-100. doi:10.1016/j.tins.2012.12.008

Bolborea, M., Pollatzek, E., Benford, H., Sotelo-Hitschfeld, T., and Dale, N. (2020). Hypothalamic Tanycytes Generate Acute Hyperphagia through Activation of the Arcuate Neuronal Network. Proc. Natl. Acad. Sci. USA 117 (25), 14473-14481. doi:10.1073/pnas.1919887117

Brown, F. D., Fessler, R. G., Rachlin, J. R., and Mullan, S. (1984). Changes in Food Intake with Electrical Stimulation of the Ventromedial Hypothalamus in Dogs. J. Neurosurg. 60 (6), 1253-1257. doi:10.3171/jns.1984.60.6.1253

Burnstock, G., and Gentile, D. (2018). The Involvement of Purinergic Signalling in Obesity. Purinergic Signal. 14 (2), 97-108. doi:10.1007/s11302-018-9605-8

Burnstock, G. (2020). Introduction to Purinergic Signalling in the Brain. Adv. Exp. Med. Biol. 1202, 1-12. doi:10.1007/978-3-030-30651-9_1

Burnstock, G. (2011). Introductory Overview of Purinergic Signalling. Front. Biosci. E3, 896-900. doi:10.2741/e298

Cai, Y., Li, H., Liu, M., Pei, Y., Zheng, J., Zhou, J., et al. (2018). Disruption of Adenosine 2A Receptor Exacerbates NAFLD through Increasing Inflammatory Responses and SREBP1c Activity. Hepatology 68 (1), 48-61. doi:10.1002/hep.29777

Carmen, G.-Y., and Víctor, S.-M. (2006). Signalling Mechanisms Regulating Lipolysis. Cell Signal. 18 (4), 401-408. doi:10.1016/j.cellsig.2005.08.009

Cham, J. L., Owens, N. C., Barden, J. A., Lawrence, A. J., and Badoer, E. (2006). P2X Purinoceptor Subtypes on Paraventricular Nucleus Neurones Projecting to the Rostral Ventrolateral Medulla in the Rat. Exp. Physiol. 91 (2), 403-411. doi:10. 1113/expphysiol.2005.032409

Chaudhari, N., and Roper, S. D. (2010). The Cell Biology of Taste. J. Cel Biol 190 (3), 285-296. doi:10.1083/jcb.201003144

Coccurello, R., and Maccarrone, M. (2018). Hedonic Eating and the "Delicious Circle": From Lipid-Derived Mediators to Brain Dopamine and Back. Front. Neurosci. 12, 271. doi:10.3389/fnins.2018.00271

Coccurello, R., and Volonté, C. (2020). P2X7 Receptor in the Management of Energy Homeostasis: Implications for Obesity, Dyslipidemia, and Insulin Resistance. Front. Endocrinol. 11, 199. doi:10.3389/fendo.2020.00199

Colldén, G., Mangano, C., and Meister, B. (2010). P2X2 Purinoreceptor Protein in Hypothalamic Neurons Associated with the Regulation of Food Intake. Neuroscience 171 (1), 62-78. doi:10.1016/j.neuroscience.2010.08.036

D’Alimonte, I., Mastrangelo, F., Giuliani, P., Pierdomenico, L., Marchisio, M., Zuccarini, M., et al. (2017). Osteogenic Differentiation of Mesenchymal Stromal Cells: A Comparative Analysis between Human Subcutaneous Adipose Tissue and Dental Pulp. Stem Cell Development 26 (11), 843-855. doi:10.1089/scd.2016.0190

D’Antongiovanni, V., Fornai, M., Pellegrini, C., Blandizzi, C., and Antonioli, L. (2020). Managing Obesity and Related Comorbidities: A Potential Pharmacological Target in the Adenosine System?. Front. Pharmacol. 11, 621955. doi:10.3389/fphar.2020.621955

de Oliveira, M., Mathias, L. S., de Sibio, M. T., Noronha-Matos, J. B., Costa, M. A., Nogueira, C. R., et al. (2020). Pitfalls and Challenges of the Purinergic Signaling Cascade in Obesity. Biochem. Pharmacol. 182, 114214. doi:10.1016/j.bcp.2020.114214

DeOliveira, C. C., Paiva Caria, C. R. e., Ferreira Gotardo, E. M., Ribeiro, M. L., and Gambero, A. (2017). Role of A 1 and A 2A Adenosine Receptor Agonists in Adipose Tissue Inflammation Induced by Obesity in Mice. Eur. J. Pharmacol. 799, 154-159. doi:10.1016/j.ejphar.2017.02.017

Depoortere, I. (2014). Taste Receptors of the Gut: Emerging Roles in Health and Disease. Gut 63 (1), 179-190. doi:10.1136/gutjnl-2013-305112

Douglass, J. D., Dorfman, M. D., and Thaler, J. P. (2017). Glia: Silent Partners in Energy Homeostasis and Obesity Pathogenesis. Diabetologia 60 (2), 226-236. doi:10.1007/s00125-016-4181-3

Faulhaber-Walter, R., Jou, W., Mizel, D., Li, L., Zhang, J., Kim, S. M., et al. (2011). Impaired Glucose Tolerance in the Absence of Adenosine A1 Receptor Signaling. Diabetes 60 (10), 2578-2587. doi:10.2337/db11-0058

Finger, T. E., Danilova, V., Barrows, J., Bartel, D. L., Vigers, A. J., Stone, L., et al. (2005). ATP Signaling Is Crucial for Communication from Taste Buds to Gustatory Nerves. Science 310 (5753), 1495-1499. doi:10.1126/science.1118435

Florenzano, F., Viscomi, M. T., Mercaldo, V., Longone, P., Bernardi, G., Bagni, C., et al. (2006). P2X2R Purinergic Receptor Subunit mRNA and Protein Are Expressed by All Hypothalamic Hypocretin/orexin Neurons. J. Comp. Neurol. 498 (1), 58-67. doi:10.1002/cne.21013

Frank, M. E., and Hettinger, T. P. (2005). What the Tongue Tells the Brain about Taste. Chem. senses 30 (Suppl. 1_1), i68-i69. doi:10.1093/chemse/bjh117
Frayling, C., Britton, R., and Dale, N. (2011). ATP-mediated Glucosensing by Hypothalamic Tanycytes. J. Physiol. 589 (Pt 9), 2275-2286. doi:10.1113/ jphysiol.2010.202051

Fredholm, B. B., IJzerman, A. P., Jacobson, K. A., Linden, J., and Müller, C. E. (2011). International Union of Basic and Clinical Pharmacology. LXXXI. Nomenclature and Classification of Adenosine Receptors-An Update. Pharmacol. Rev. 63 (1), 1-34. doi:10.1124/pr.110.003285

García-Cáceres, C., Balland, E., Prevot, V., Luquet, S., Woods, S. C., Koch, M., et al. (2019). Role of Astrocytes, Microglia, and Tanycytes in Brain Control of Systemic Metabolism. Nat. Neurosci. 22 (1), 7-14. doi:10.1038/s41593-018-0286-y

García-Cáceres, C., Quarta, C., Varela, L., Gao, Y., Gruber, T., Legutko, B., et al. (2016). Astrocytic Insulin Signaling Couples Brain Glucose Uptake with Nutrient Availability. Cell 166 (4), 867-880. doi:10.1016/j.cell.2016.07.028

Gharibi, B., Abraham, A. A., Ham, J., and Evans, B. A. J. (2012). Contrasting Effects of $\mathrm{A} 1$ and $\mathrm{A} 2 \mathrm{~b}$ Adenosine Receptors on Adipogenesis. Int. J. Obes. 36 (3), 397-406. doi:10.1038/ijo.2011.129

Gnad, T., Navarro, G., Lahesmaa, M., Reverte-Salisa, L., Copperi, F., Cordomi, A., et al. (2020). Adenosine/A2B Receptor Signaling Ameliorates the Effects of Aging and Counteracts Obesity. Cel Metab. 32 (1), 56-70. doi:10.1016/j.cmet.2020.06.006

Gnad, T., Scheibler, S., von Kügelgen, I., Scheele, C., Kilić, A., Glöde, A., et al. (2014). Adenosine Activates Brown Adipose Tissue and Recruits Beige Adipocytes via A2A Receptors. Nature 516 (7531), 395-399. doi:10.1038/nature13816

González-Benítez, E., Guinzberg, R., Díaz-Cruz, A., and Piña, E. (2002). Regulation of Glycogen Metabolism in Hepatocytes through Adenosine Receptors. Role of Ca2+ and cAMP. Eur. J. Pharmacol. 437 (3), 105-111. doi:10.1016/s0014-2999(02)01299-2

Goodman, T., and Hajihosseini, M. K. (2015). Hypothalamic Tanycytes-Masters and Servants of Metabolic, Neuroendocrine, and Neurogenic Functions. Front. Neurosci. 9 (387). doi:10.3389/fnins.2015.00387

Greenberg, J. A., Boozer, C. N., and Geliebter, A. (2006). Coffee, Diabetes, and Weight Control. Am. J. Clin. Nutr. 84 (4), 682-693. doi:10.1093/ajcn/84.4.682

Gropp, E., Shanabrough, M., Borok, E., Xu, A. W., Janoschek, R., Buch, T., et al. (2005). Agouti-related Peptide-Expressing Neurons Are Mandatory for Feeding. Nat. Neurosci. 8 (10), 1289-1291. doi:10.1038/nn1548

Jain, S., and Jacobson, K. A. (2020). Purinergic Signaling in Diabetes and Metabolism. Biochem. Pharmacol., 25, 114393. doi:10.1016/j.bcp.2020.114393

Jain, S., Pydi, S. P., Toti, K. S., Robaye, B., Idzko, M., Gavrilova, O., et al. (2020). Lack of Adipocyte Purinergic P2Y6receptor Greatly Improves Whole Body Glucose Homeostasis. Proc. Natl. Acad. Sci. USA 117 (48), 30763-30774. doi:10. 1073/pnas.2006578117

Johansson, S. M., Salehi, A., Sandström, M. E., Westerblad, H., Lundquist, I., Carlsson, P.-O., et al. (2007). A1 Receptor Deficiency Causes Increased Insulin and Glucagon Secretion in Mice. Biochem. Pharmacol. 74 (11), 1628-1635. doi:10.1016/j.bcp.2007.08.006

Kaufman, A., Choo, E., Koh, A., and Dando, R. (2018). Inflammation Arising from Obesity Reduces Taste Bud Abundance and Inhibits Renewal. PLoS Biol. 16 (3), e2001959. doi:10.1371/journal.pbio.2001959

Kettenmann, H., Hanisch, U.-K., Noda, M., and Verkhratsky, A. (2011). Physiology of Microglia. Physiol. Rev. 91 (2), 461-553. doi:10.1152/physrev.00011.2010

Khan, A. S., Keast, R., and Khan, N. A. (2020). Preference for Dietary Fat: From Detection to Disease. Prog. Lipid Res. 78, 101032. doi:10.1016/j.plipres.2020.101032

Kittner, H., Franke, H., Harsch, J. I., El-Ashmawy, I. M., Seidel, B., Krügel, U., et al. (2006). Enhanced Food Intake after Stimulation of Hypothalamic P2Y1receptors in Rats: Modulation of Feeding Behaviour by Extracellular Nucleotides. Eur. J. Neurosci. 24 (7), 2049-2056. doi:10.1111/j.1460-9568.2006.05071.x

Kittner, H., Krügel, U., El-Ashmawy, I. M., and Illes, P. (2000). Suppression of Feeding-Evoked Dopamine Release in the Rat Nucleus Accumbens by the Blockade of P2 Purinoceptors. Eur. J. Pharmacol. 406 (3), R13-R14. doi:10. 1016/s0014-2999(00)00731-7

Kittner, H., Krügel, U., Hoffmann, E., and Illes, P. (2004). Modulation of Feeding Behaviour by Blocking Purinergic Receptors in the Rat Nucleus Accumbens: a Combined Microdialysis, Electroencephalographic and Behavioural Study. Eur. J. Neurosci. 19 (2), 396-404. doi:10.1111/j.0953-816x.2003.03090.x

Krügel, U., Kittner, H., Franke, H., and Illes, P. (2003). Purinergic Modulation of Neuronal Activity in the Mesolimbic Dopaminergic System In Vivo. Synapse 47 (2), 134-142. doi:10.1002/syn.10162

Krügel, U., Kittner, H., and Illes, P. (2001). Mechanisms of Adenosine 5'-TriphosphateInduced Dopamine Release in the Rat Nucleus Accumbens In Vivo. Synapse 39 (3), 222-232. doi:10.1002/1098-2396(20010301)39:3<222::Aid-syn1003>3.0.Co;2-r 
Kusminski, C. M., Bickel, P. E., and Scherer, P. E. (2016). Targeting Adipose Tissue in the Treatment of Obesity-Associated Diabetes. Nat. Rev. Drug Discov. 15 (9), 639-660. doi:10.1038/nrd.2016.75

Laplante, M.-A., Monassier, L., Freund, M., Bousquet, P., and Gachet, C. (2010). The Purinergic P2Y1 Receptor Supports Leptin Secretion in Adipose Tissue. Endocrinology 151 (5), 2060-2070. doi:10.1210/en.2009-1134

Lechan, R. M. T. R. (2016). Functional Anatomy of the Hypothalamus and Pituitary. South Dartmouth (MA): Endotext.

Lee, S. C., Vielhauer, N. S., Leaver, E. V., and Pappone, P. A. (2005). Differential Regulation of $\mathrm{Ca} 2+$ Signaling and Membrane Trafficking by Multiple P2 Receptors in Brown Adipocytes. J. Membr. Biol 207 (3), 131-142. doi:10. 1007/s00232-005-0808-x

Léon, C., Freund, M., Latchoumanin, O., Farret, A., Petit, P., Cazenave, J.-P., et al. (2005). The P2Y1 Receptor Is Involved in the Maintenance of Glucose Homeostasis and in Insulin Secretion in Mice. Purinergic Signal. 1 (2), 145-151. doi:10.1007/s11302-005-6209-x

Li, W., Li, G., Zhang, Y., Wei, S., Song, M., Wang, W., et al. (2015). Role of P2×7 Receptor in the Differentiation of Bone Marrow Stromal Cells into Osteoblasts and Adipocytes. Exp. Cel Res. 339 (2), 367-379. doi:10.1016/j.yexcr.2015.10.011

Losenkova, K., Zuccarini, M., Helenius, M., Jacquemet, G., Gerasimovskaya, E., Tallgren, C., et al. (2018). Endothelial Cells Cope with Hypoxia-Induced Depletion of ATP via Activation of Cellular Purine Turnover and Phosphotransfer Networks. Biochim. Biophys. Acta (Bba) - Mol. Basis Dis. 1864 (5 Pt A), 1804-1815. doi:10.1016/j.bbadis.2018.03.001

Matsumoto, N., Sorimachi, M., and Akaike, N. (2004). Excitatory Effects of ATP on Rat Dorsomedial Hypothalamic Neurons. Brain Res. 1009 (1-2), 234-237. doi:10.1016/j.brainres.2004.03.001

Merz, J., Albrecht, P., von Garlen, S., Ahmed, I., Dimanski, D., Wolf, D., et al. (2018). Purinergic Receptor Y2 (P2Y2)- Dependent VCAM-1 Expression Promotes Immune Cell Infiltration in Metabolic Syndrome. Basic Res. Cardiol. 113 (6), 45. doi:10.1007/s00395-018-0702-1

Mingote, S., Pereira, M., Farrar, A. M., McLaughlin, P. J., and Salamone, J. D. (2008). Systemic Administration of the Adenosine A2A Agonist CGS 21680 Induces Sedation at Doses that Suppress Lever Pressing and Food Intake. Pharmacol. Biochem. Behav. 89 (3), 345-351. doi:10.1016/j.pbb.2008.01.006

Nascimento, E. B. M., Boon, M. R., and Lichtenbelt, W. D. v. M. (2014). Fat Cells Gain New Identities. Sci. Transl. Med. 6 (247), 247fs29. doi:10.1126/scitranslmed.3009809

Nelson, G., Hoon, M. A., Chandrashekar, J., Zhang, Y., Ryba, N. J. P., and Zuker, C. S. (2001). Mammalian Sweet Taste Receptors. Cell 106 (3), 381-390. doi:10. 1016/s0092-8674(01)00451-2

Orellana, J. A., Sáez, P. J., Cortés-campos, C., Elizondo, R. J., Shoji, K. F., ContrerasDuarte, S., et al. (2012). Glucose Increases Intracellular Free Ca2+ in Tanycytes via ATP Released through Connexin 43 Hemichannels. Glia 60 (1), 53-68. doi:10.1002/glia.21246

Peña-Altamira, L. E., Polazzi, E., Giuliani, P., Beraudi, A., Massenzio, F., Mengoni, I., et al. (2018). Release of Soluble and Vesicular Purine Nucleoside Phosphorylase from Rat Astrocytes and Microglia Induced by Proinflammatory Stimulation with Extracellular ATP via P2X 7 Receptors. Neurochem. Int. 115, 37-49. doi:10.1016/j.neuint.2017.10.010

Proserpio, C., Laureati, M., Bertoli, S., Battezzati, A., and Pagliarini, E. (2015). Determinants of Obesity in Italian Adults: the Role of Taste Sensitivity, Food Liking, and Food Neophobia. Chem. Senses 41 (2), 169-176. doi:10.1093/ chemse/bjv072

Rodgers, R. J., Tschöp, M. H., and Wilding, J. P. H. (2012). Anti-obesity Drugs: Past, Present and Future. Dis. Models Mech. 5 (5), 621-626. doi:10.1242/dmm. 009621

Sacramento, J. F., Martins, F. O., Rodrigues, T., Matafome, P., Ribeiro, M. J., Olea, E., et al. (2020). A2 Adenosine Receptors Mediate Whole-Body Insulin Sensitivity in a Prediabetes Animal Model: Primary Effects on Skeletal Muscle. Front. Endocrinol. 11, 262. doi:10.3389/fendo.2020.00262

Seidel, B., Bigl, M., Franke, H., Kittner, H., Kiess, W., Illes, P., et al. (2006a). Expression of Purinergic Receptors in the Hypothalamus of the Rat Is Modified by Reduced Food Availability. Brain Res. 1089 (1), 143-152. doi:10.1016/j. brainres.2006.03.038

Seidel, B., Bigl, M., Franke, H., Kittner, H., Kiess, W., Illes, P., et al. (2006b). Expression of Purinergic Receptors in the Hypothalamus of the Rat Is Modified by Reduced Food Availability. Brain Res. 1089 (1), 143-152. doi:10.1016/j. brainres.2006.03.038
Steculorum, S. M., Paeger, L., Bremser, S., Evers, N., Hinze, Y., Idzko, M., et al. (2015a). Hypothalamic UDP Increases in Obesity and Promotes Feeding via P2Y6-dependent Activation of AgRP Neurons. Cell 162 (6), 1404-1417. doi:10.1016/j.cell.2015.08.032

Steculorum, S. M., Paeger, L., Bremser, S., Evers, N., Hinze, Y., Idzko, M., et al. (2015b). Hypothalamic UDP Increases in Obesity and Promotes Feeding via P2Y6-dependent Activation of AgRP Neurons. Cell 162 (6), 1404-1417. doi:10. 1016/j.cell.2015.08.032

Steculorum, S. M., Timper, K., Engström Ruud, L., Evers, N., Paeger, L., Bremser, S., et al. (2017a). Inhibition of P2Y6 Signaling in AgRP Neurons Reduces Food Intake and Improves Systemic Insulin Sensitivity in Obesity. Cel Rep. 18 (7), 1587-1597. doi:10.1016/j.celrep.2017.01.047

Steculorum, S. M., Timper, K., Engström Ruud, L., Evers, N., Paeger, L., Bremser, S., et al. (2017b). Inhibition of P2Y6 Signaling in AgRP Neurons Reduces Food Intake and Improves Systemic Insulin Sensitivity in Obesity. Cel Rep. 18 (7), 1587-1597. doi:10.1016/j.celrep.2017.01.047

Sun, S., Xia, S., Ji, Y., Kersten, S., and Qi, L. (2012). The ATP-P2x7 Signaling axis Is Dispensable for Obesity-Associated Inflammasome Activation in Adipose Tissue. Diabetes 61 (6), 1471-1478. doi:10.2337/db11-1389

Takaki, A., Aou, S., Oomura, Y., Okada, E., and Hori, T. (1992). Feeding Suppression Elicited by Electrical and Chemical Stimulations of Monkey Hypothalamus. Am. J. Physiology-Regulatory, Integr. Comp. Physiol. 262 (4), R586-R594. doi:10.1152/ajpregu.1992.262.4.R586

Thaler, J. P., Yi, C.-X., Schur, E. A., Guyenet, S. J., Hwang, B. H., Dietrich, M. O., et al. (2012). Obesity Is Associated with Hypothalamic Injury in Rodents and Humans. J. Clin. Invest. 122 (1), 153-162. doi:10.1172/jci59660

Timper, K., and Brüning, J. C. (2017). Hypothalamic Circuits Regulating Appetite and Energy Homeostasis: Pathways to Obesity. Dis. Model. Mech. 10 (6), 679-689. doi:10.1242/dmm.026609

Tozzi, M., and Novak, I. (2017). Purinergic Receptors in Adipose Tissue as Potential Targets in Metabolic Disorders. Front. Pharmacol. 8, 878. doi:10. 3389/fphar.2017.00878

Wang, D., Wang, H., Gao, H., Zhang, H., Zhang, H., Wang, Q., et al. (2020). P2X7 Receptor Mediates NLRP3 Inflammasome Activation in Depression and Diabetes. Cell Biosci 10, 28. doi:10.1186/s13578-020-00388-1

Wollmann, G., Acuna-Goycolea, C., and van den Pol, A. N. (2005). Direct Excitation of Hypocretin/orexin Cells by Extracellular ATP at P2X Receptors. J. Neurophysiol. 94 (3), 2195-2206. doi:10.1152/jn.00035.2005

Wu, L., Meng, J., Shen, Q., Zhang, Y., Pan, S., Chen, Z., et al. (2017). Caffeine Inhibits Hypothalamic A1R to Excite Oxytocin Neuron and Ameliorate Dietary Obesity in Mice. Nat. Commun. 8, 15904. doi:10.1038/ncomms15904

Yang, L., Qi, Y., and Yang, Y. (2015). Astrocytes Control Food Intake by Inhibiting AGRP Neuron Activity via Adenosine A1 Receptors. Cel Rep. 11 (5), 798-807. doi:10.1016/j.celrep.2015.04.002

Yasuda, N., Inoue, T., Horizoe, T., Nagata, K., Minami, H., Kawata, T., et al. (2003). Functional Characterization of the Adenosine Receptor Contributing to Glycogenolysis and Gluconeogenesis in Rat Hepatocytes. Eur. J. Pharmacol. 459 (2-3), 159-166. doi:10.1016/s0014-2999(02)02832-7

Yegutkin, G. G. (2014). Enzymes Involved in Metabolism of Extracellular Nucleotides and Nucleosides: Functional Implications and Measurement of Activities. Crit. Rev. Biochem. Mol. Biol. 49 (6), 473-497. doi:10.3109/10409238.2014.953627

Zhang, Y., Ecelbarger, C. M., Lesniewski, L. A., Müller, C. E., and Kishore, B. K. (2020). P2Y2 Receptor Promotes High-Fat Diet-Induced Obesity. Front. Endocrinol. 11, 341. doi:10.3389/fendo.2020.00341

Zimmermann, H., Zebisch, M., and Sträter, N. (2012). Cellular Function and Molecular Structure of Ecto-Nucleotidases. Purinergic Signal. 8 (3), 437-502. doi:10.1007/s11302-012-9309-4

Conflict of Interest: The authors declare that the research was conducted in the absence of any commercial or financial relationships that could be construed as a potential conflict of interest.

Copyright (c) 2021 Caruso, Zuccarini, Di Iorio, Muhammad and Ronci. This is an open-access article distributed under the terms of the Creative Commons Attribution License (CC BY). The use, distribution or reproduction in other forums is permitted, provided the original author $(s)$ and the copyright owner $(s)$ are credited and that the original publication in this journal is cited, in accordance with accepted academic practice. No use, distribution or reproduction is permitted which does not comply with these terms. 